\title{
Bone and Shell Tools and Ornament from the Feature 2 Midden Mound at the A. C. Saunders Site (41AN19), Anderson County, Texas
}

Timothy K. Perttula

Heritage Research Center, Stephen F. Austin State University

Follow this and additional works at: https://scholarworks.sfasu.edu/ita

Part of the American Material Culture Commons, Archaeological Anthropology Commons, Environmental Studies Commons, Other American Studies Commons, Other Arts and Humanities Commons, Other History of Art, Architecture, and Archaeology Commons, and the United States History Commons

Tell us how this article helped you.

This Article is brought to you for free and open access by the Center for Regional Heritage Research at SFA ScholarWorks. It has been accepted for inclusion in Index of Texas Archaeology: Open Access Gray Literature from the Lone Star State by an authorized editor of SFA ScholarWorks. For more information, please contact cdsscholarworks@sfasu.edu. 
Bone and Shell Tools and Ornament from the Feature 2 Midden Mound at the A. C. Saunders Site (41AN19), Anderson County, Texas

\section{Creative Commons License}

\section{(c) (1) \&}

This work is licensed under a Creative Commons Attribution-NonCommercial 4.0 International License 


\title{
Bone and Shell Tools and Ornament from the Feature 2 Midden Mound at the A. C. Saunders Site (41AN19), Anderson County, Texas
}

\author{
Timothy K. Perttula
}

\section{Introduction}

The A.C. Saunders site (41AN19) is an important ancestral Caddo settlement in the upper Neches River basin in Anderson County in East Texas (Figure 1). The site is one of only a few ancestral Caddo sites with mound features in the upper Neches River basin, particularly those that are known to date after ca. A.D. 1400, but this part of the upper Neches River basin, including its

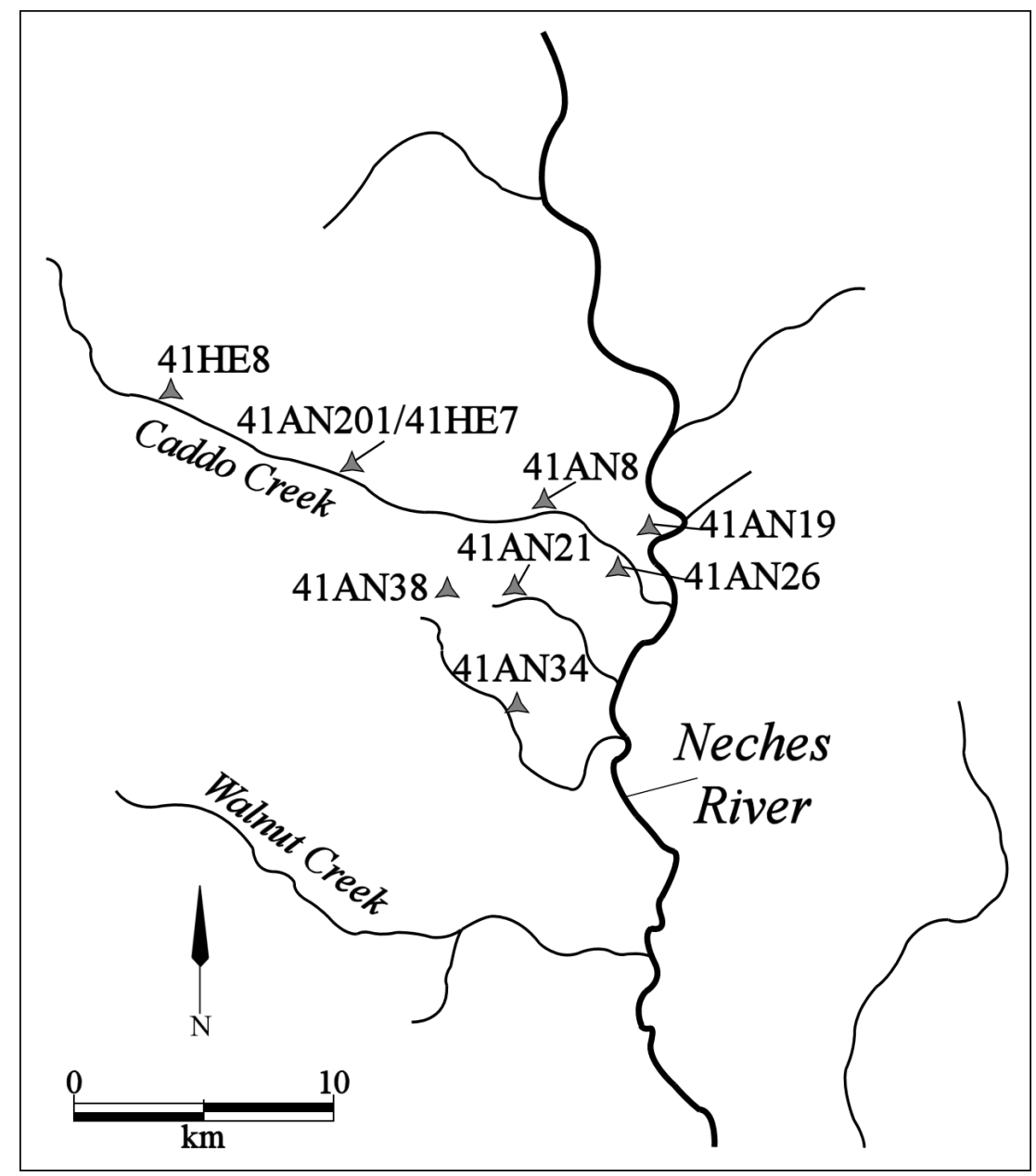

Figure 1. The A. C. Saunders site in the upper Neches River basin and important excavated Caddo sites in the Caddo Creek valley and surrounding drainages in Anderson and Henderson counties, Texas.

Journal of Northeast Texas Archaeology, Volume 84, 2020 
many tributaries, such as Caddo Creek just to the south and west (see Perttula and Walters 2016), was widely settled by Caddo farmers after that time. These Caddo groups left behind evidence of year-round occupied settlements with house structures, middens, and outdoor activity areas, impressive artifact assemblages, as well as the creation of numerous cemeteries, most apparently the product of use by families or lineage groups.

\section{The Cultural Setting of the A. C. Saunders Site}

What makes the A. C. Saunders site unique in upper Neches River basin Caddo archaeology are the two mound features there, situated on a broad upland landform less than a mile west of the Neches River and a comparable distance north of the confluence of Caddo Creek with the Neches River (see Figure 1). The first mound (Feature 1) is an ash mound that has been linked with the use of fire temples and perpetual fires by the xinesi of Hasinai Caddo groups in historic times (Jackson 1936; Kleinschmidt 1982, 1984; Perttula 1992; Wyckoff and Baugh 1980). The second mound (Feature 2), not far to the southeast, is a thick midden mound that accumulated over a large structure. The concentrated midden accumulation near the ash mound suggests it may represent the remains of multiple feasting events (e.g., Kassabaum 2019) and other ritual activities where large amounts of food were consumed, clay pipes were smoked, and cooking and serving vessels were used, and thus the discarded fragments of these activities created the midden deposits. These items constitute a discrete and substantial corpus of material culture remains that have played a large role in defining and framing the archaeological character of what has come to be known as the Late Caddo period Frankston phase (ca. A.D. 1400-1680), since the A. C. Saunders site is the quintessential Frankston phase site in East Texas. As such, these material culture remains curated at the Texas Archeological Research Laboratory at The University of Texas at Austin are a means to better understand the character of the tools and ornaments, the everyday things, used by Caddo peoples in the upper Neches River basin.

\section{Feature 2, Midden Mound}

UT archaeologists completed excavations at the A. C. Saunders site in 1931 and 1935 (Jackson $1935,1936)$. This work focused solely on the two mounds (Figure 2), with no investigations done to identify non-mound habitation areas or associated cemetery areas. The Feature 2 midden mound was approximately $125 \mathrm{ft}$. $(38.1 \mathrm{~m})$ south-southeast of Feature 1 . The midden mound, which was $60 \times 50 \mathrm{ft}$. in length and width $(18.3 \times 15.2 \mathrm{~m})$ and stood $2.6 \mathrm{ft}$. in height $(0.8 \mathrm{~m})$, was totally excavated in 1935 in a ca. $55 \mathrm{ft}$. square unit, with organically-enriched midden deposits with ash removed in three 10 inch levels labeled ACS 1, ACS 2, and ACS 3 (Jackson 1936:136, 153). Directly beneath the midden deposits was evidence that a large circular structure (Feature 3), marked by an arc of 99 post holes identifying the outer wall of the structure (Perttula 2020:Figures 6 and 7), stood here and was subsequently buried by the midden mound deposits. Several interior post holes may represent the center post (12 inches and diameter and $2.5 \mathrm{ft}$. in depth) as well as various internal partitions.

The midden deposits above Feature 3 contained an abundance of ceramic sherds, estimated at 600 lbs. in weight (Jackson 1936:139), as well as ca. 400 lbs. of well-preserved animal bone and fresh water mussel shell. The recent analysis of the ceramic vessel sherds from Feature 2 suggest it accumulated from ca. A.D. 1480 to the early $17^{\text {th }}$ century (Perttula 2020).

Only a small portion of the animal bones and mussel shell remains were retained by The University of Texas archaeologists, unfortunately, including only 527 mussel shell valves (Neck 


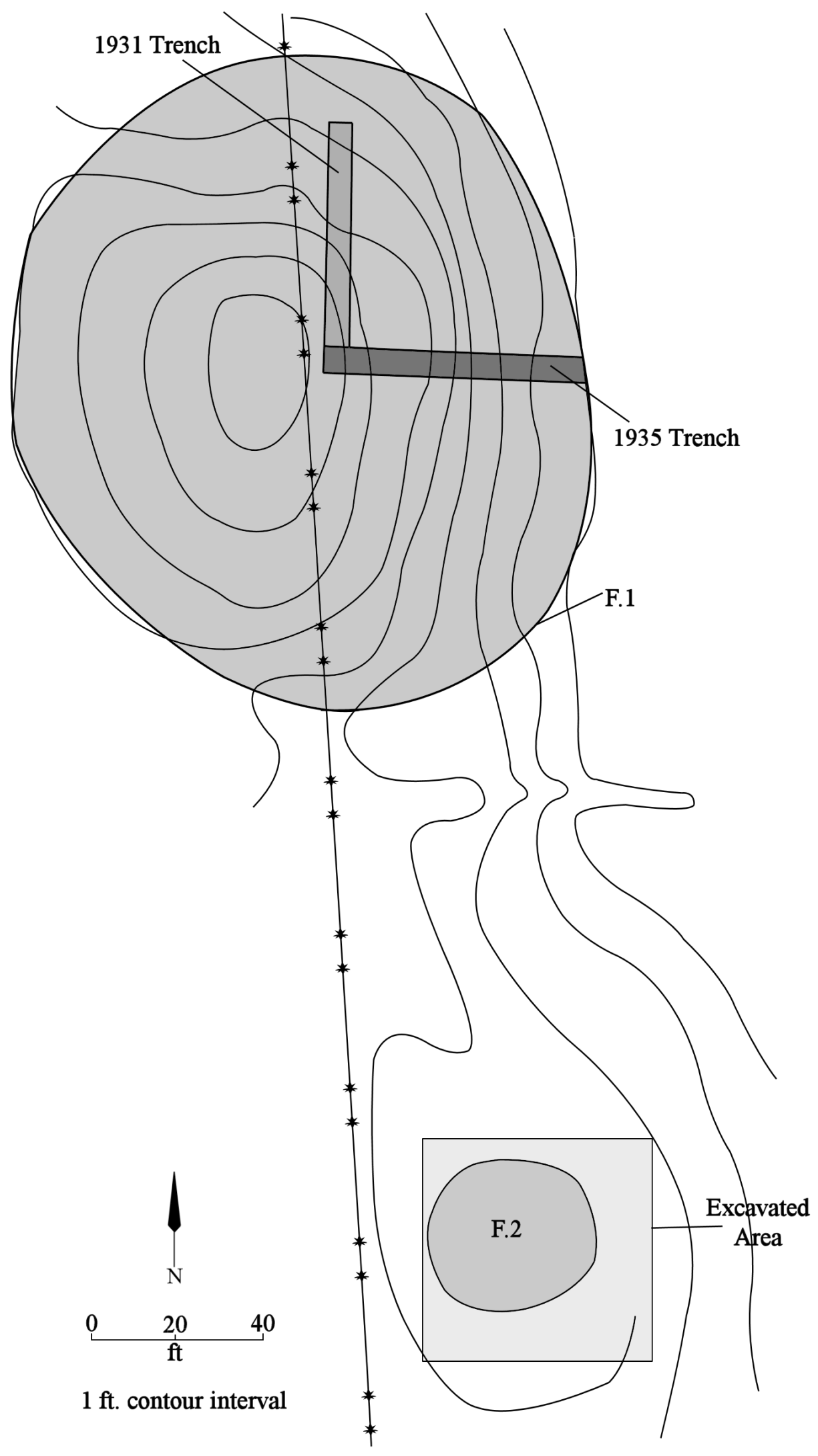

Figure 2. Feature 1 and 2 mounds at the A. C. Saunders Site. 
1982) and 151 animal remains (Kleinschmidt 1982:266-271). The bone tools, shell tools, and shell ornament remaining in the collections from Feature 2 are the subject of this article.

\section{Bone Tools}

There are 69 animal bone tools in the A. C. Saunders collection, most of them made from deer bone. Most of these are either ulna tools (Figure 3a-c, n=34) or antler tools (Figure 4, n=15).

The deer ulna tools may have been used as awls to pierce hide or leather. The pieces have modified distal shafts with visible striations, smoothing, or polishing from repeated use. The distal ends range from square or rounded with blunt ends, or pointed, and the modified shafts range from $1.8-6.7 \mathrm{~cm}$ in length.

Most of the deer antler tines $(n=15)$ have been rounded or smoothed to a blunt end, and they range from 10.2-16.1 cm in length, but others have been sharpened to a point, perhaps used for lithic knapping and working to pierce or cut deer hides. One of the antler tines had been cut at both ends, possibly forming a bone bead (Jackson 1935:Figure 12d).

Four tools are made from deer metatarsals (Figure 5) and are likely beamers used in deer hide cleaning. They have been smoothed or polished on their shafts, and one had been split length-wise to create two separate tools, one sharpened to a point.

One piece from a deer metacarpal bone has been made into a tool by smoothing its entire shaft, possibly for deer hide work. Ten deer bone pieces are thin tubular fragments with smoothing and polishing, possibly from use as needles or pins (Figure 6a-b).

There are also five bird bone tools in the assemblage. Four have been smoothed, two of these as long points that are probably needles or pins, and one is a hollowed-out long bone tube (Figure 7). Jackson (1935:25) suggests this may have been a bone bead.

\section{Shell Tools}

The shell tools $(\mathrm{n}=18)$ are on complete or nearly complete freshwater mussel shell valves. Eleven of the valves from Tritogonia verrucosa and Lampsilis teres have use wear on the bottom edges of the valves (Kleinschmidt 1982:66 and Figure 10), perhaps from use as spoons or digging tools. The other seven have single drilled or punched perforations on the upper valves (Figure 8ab). These are from Plectomerus dombyanus, Amblema plicata, Lamspilis hydiana, and Tritogonia verrucosa species.

Experimental archaeological work and micro-wear studies on burins summarized by Robinson (2020) from the Edd Melton site (41BL1138) has made a strong case that such single perforated mussel shell valves were used as net weights. These shells would likely have been tied to the bottom parts of net cordage to function as weights or sinkers.

\section{Shell Ornament}

The one shell ornament in the A. C. Saunders collection is a marine shell columella fragment from a conch or whelk, likely collected from the Gulf of Mexico. The columella has been split lengthwise, and then two small holes were drilled through one end (Figure 9), likely for suspension on a necklace. 

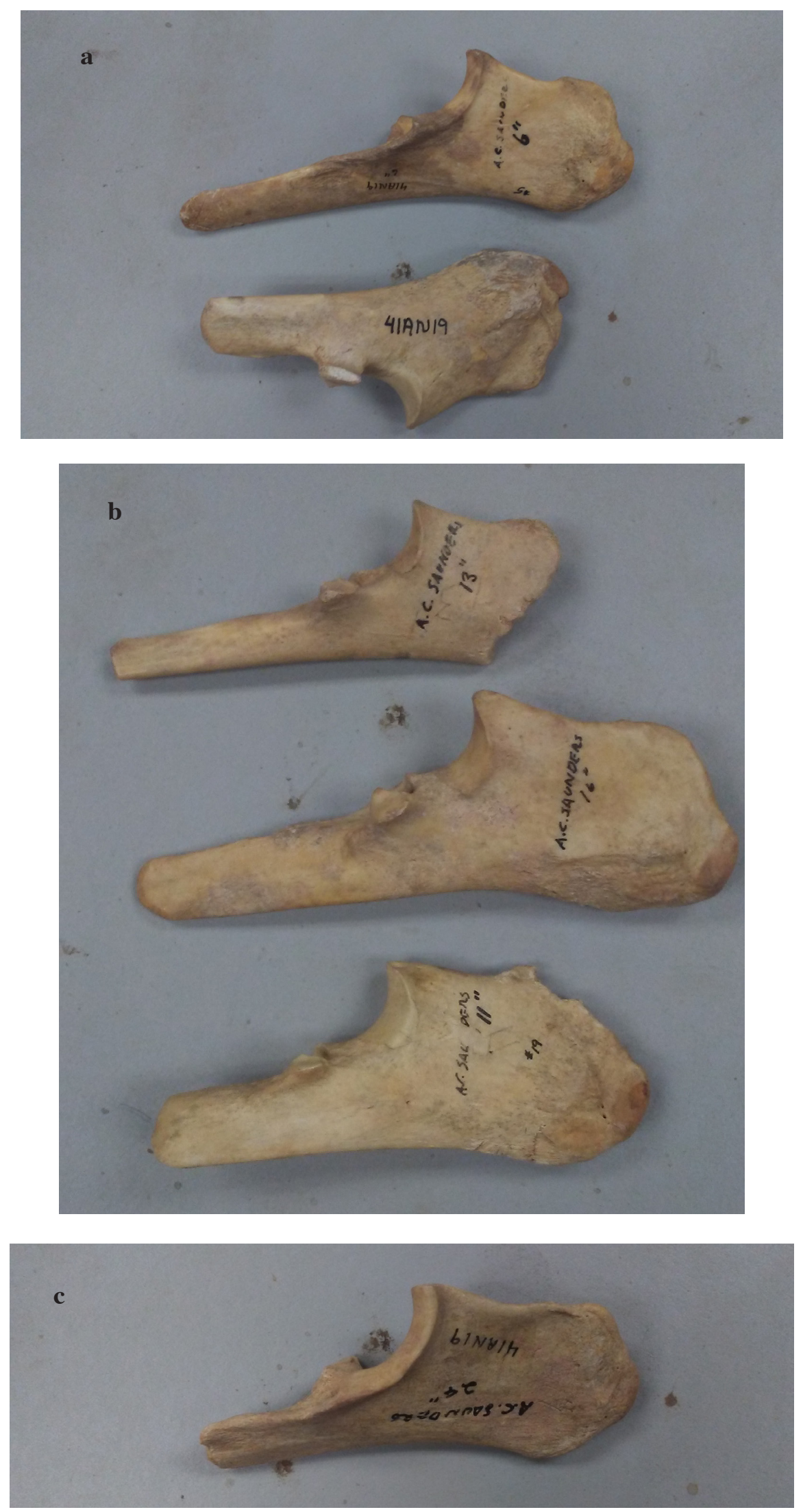

Figure 3. Deer ulna tools from the A. C. Saunders site: a, ACS 1; b, ACS 2; c, ACS 3. 


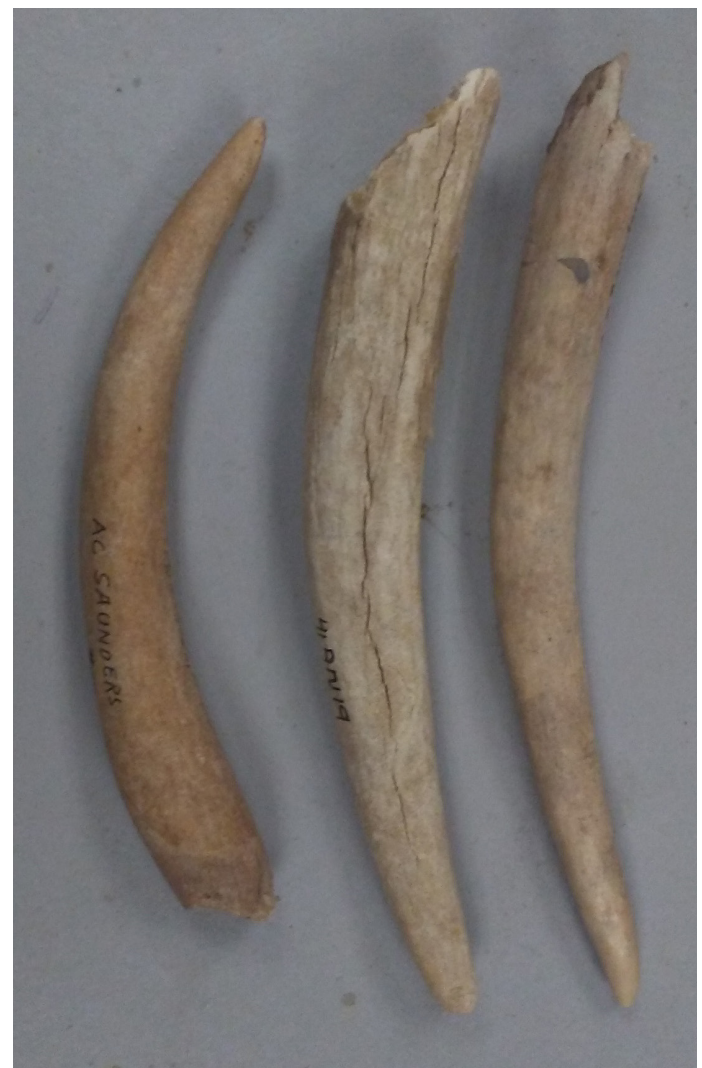

Figure 4. Deer antler tools from the A. C. Saunders site, no recorded provenience.

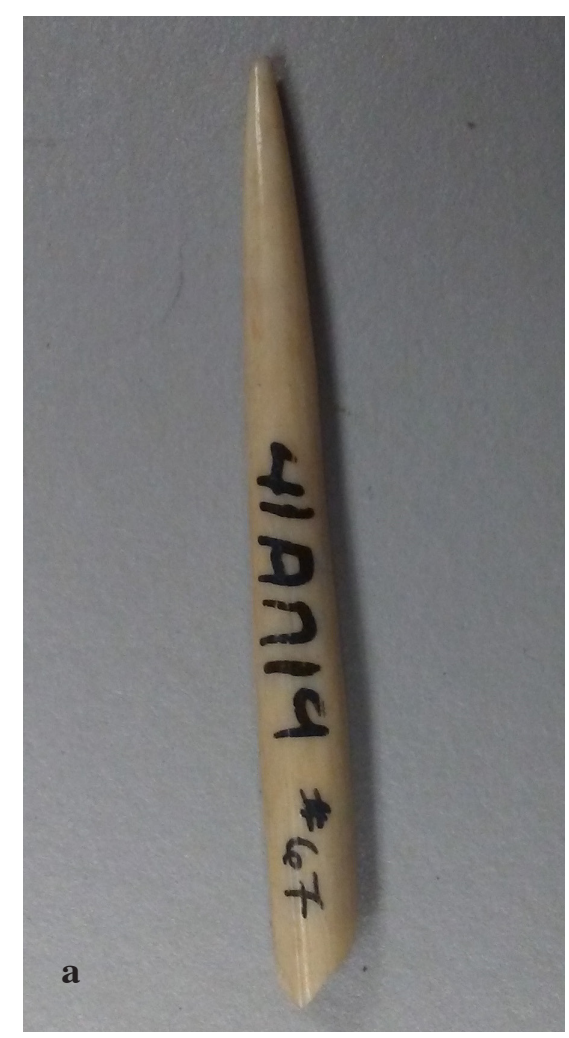

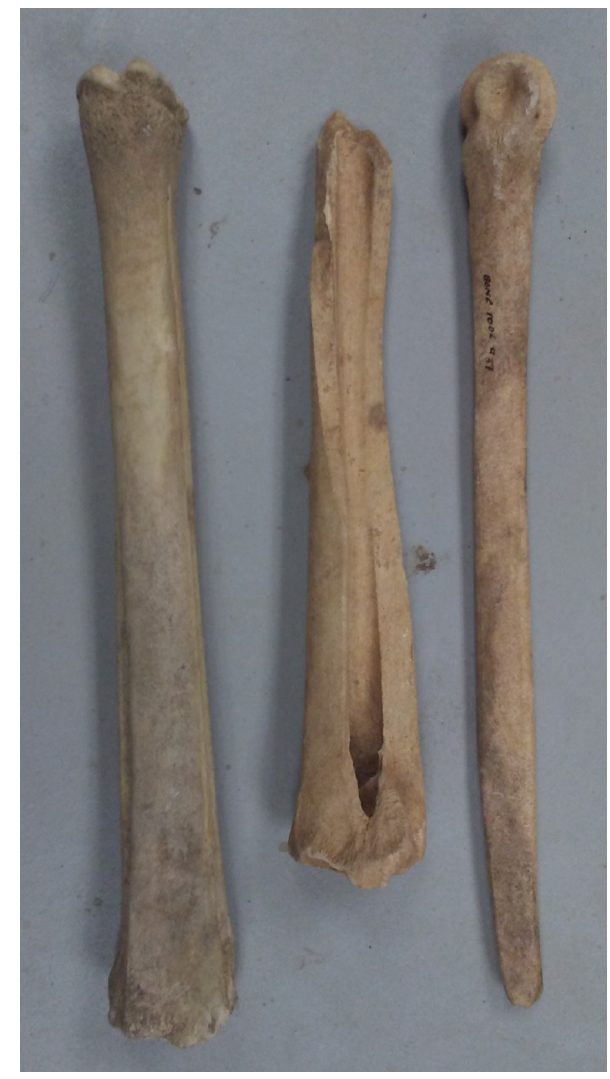

Figure 5. Deer metatarsal tools from the A. C. Saunders site, no provenience.

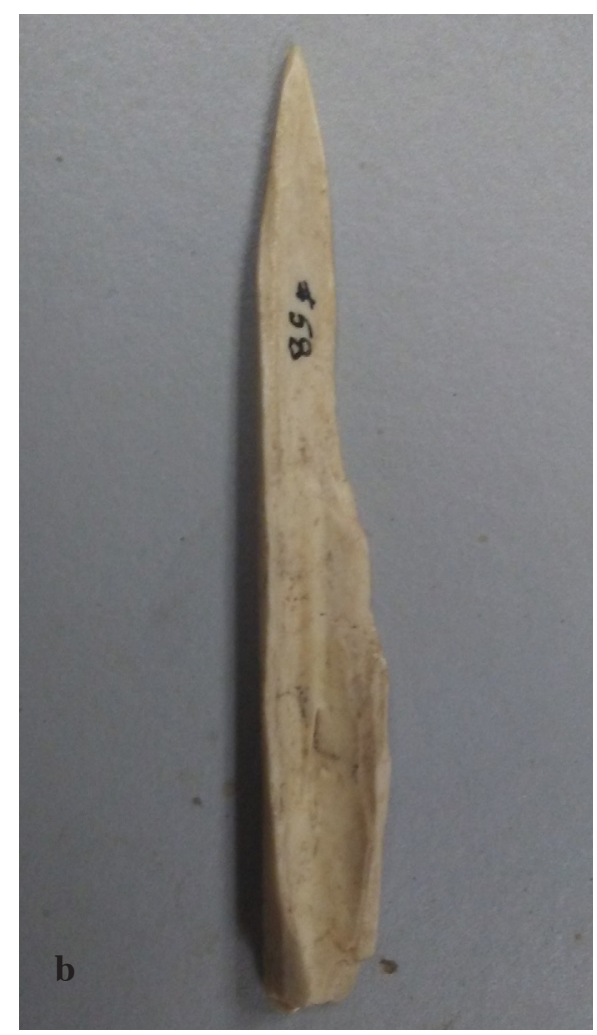

Figure 6. Polished bone needles or pins from the A. C. Saunders site: a, ACS 1; b, ACS 3. 


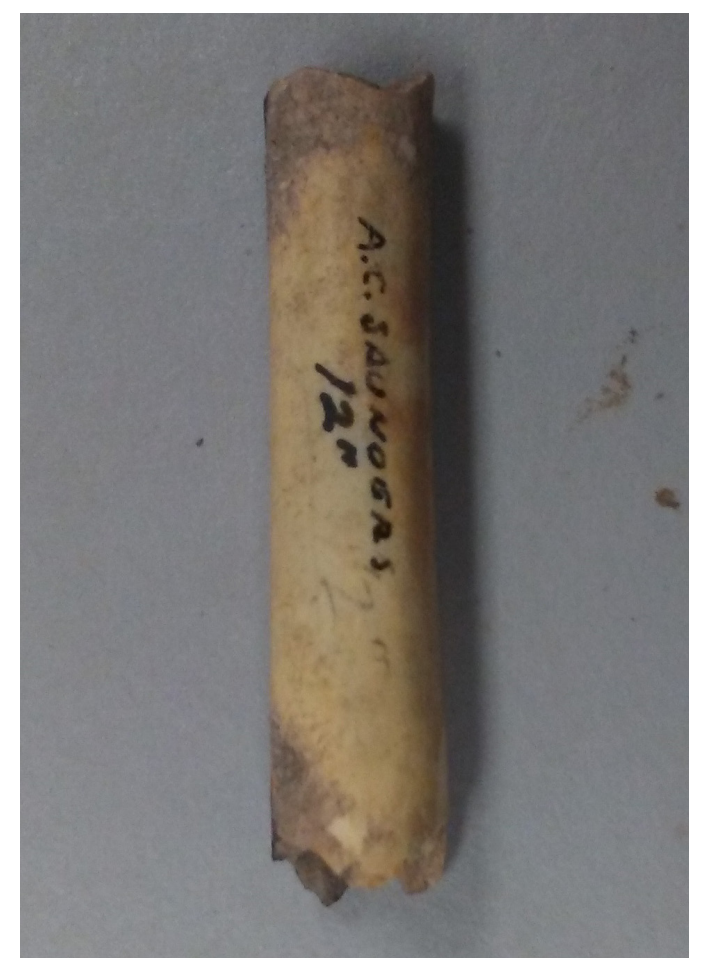

Figure 7. Bird bone tube or possible bead from the A. C. Saunders site, ACS 2.
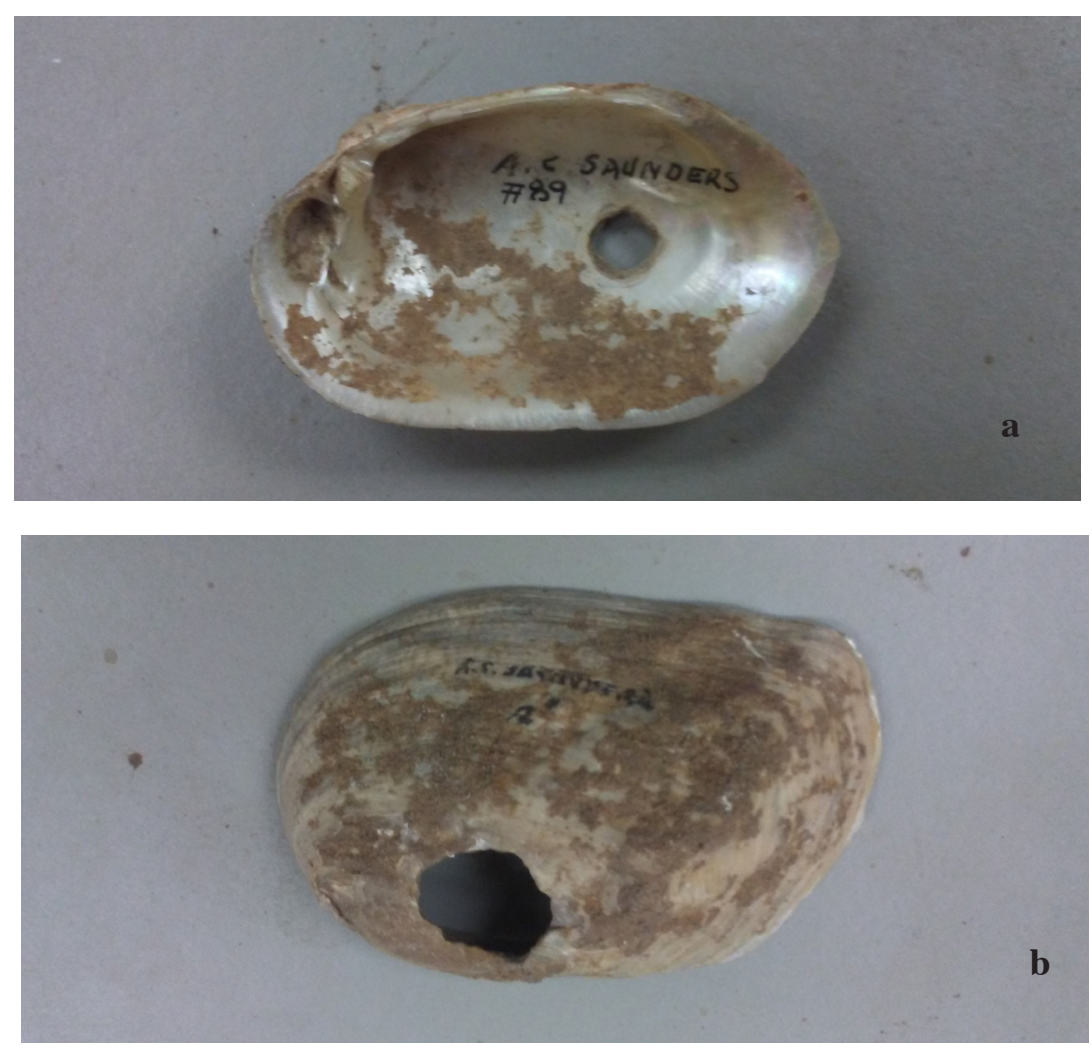

Figure 8. Perforated mussel shell valves from the A. C. Saunders site: a; Lampsilis hydiana, no provenience; b, Plectomerus dombyanus, ACS 2. 


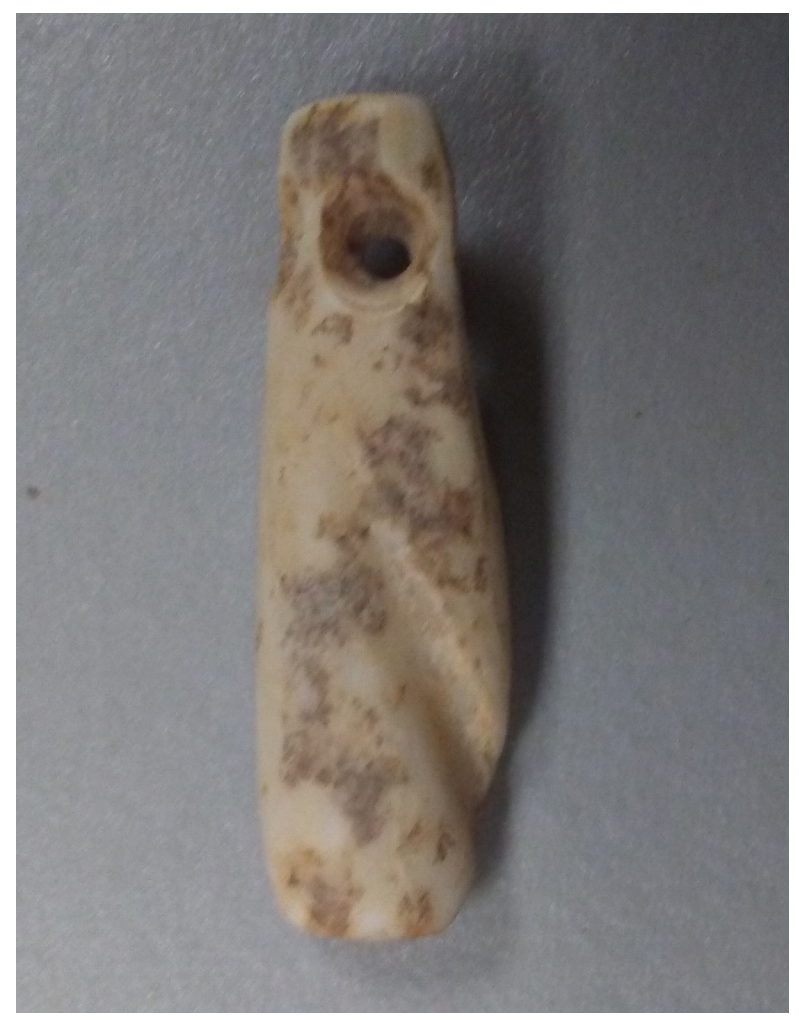

Figure 9. Drilled columella ornament from the A. C. Saunders site, no provenience.

\section{Summary and Conclusions}

During the extensive archaeological investigations in 1935 by the University of Texas (UT) of the Feature 2 midden mound at the A. C. Saunders site (41AN19) in the upper Neches River basin, a number of bone and shell tools, and a shell ornament, were recovered and retained in UT collections, where they are still available for study. I discuss and illustrate representative examples of several kinds of bone and shell tools preserved in ca. A.D. 1480-early $17^{\text {th }}$ century Frankston phase Feature 2 midden deposits where domestic and feasting remains accumulated. The deer bone tools include ulna awls, antler flakers, metatarsal and metacarpal beamers, as well as deer and bird bone needles or pins. There is also one possible bird bone bead in the collection.

Freshwater mussels were likely gathered for food by ancestral Caddo peoples during certain seasons of the year, and their valves were mainly discarded in the Feature 2 midden deposits as food trash. However, a certain number of the valves have evidence of use along their edges, either from being used as spoons or digging implements, or the valves have a single perforated or drilled hole. It is likely that these perforated mussel shell valves were net weights, suggesting that not only did the ancestral Caddo peoples at A. C. Saunders make and use cordage for nets, but that they harvested fish from the Neches River with these nets.

\section{Acknowledgments}

Thanks to Marybeth Tomka and Annie Riegert for accessing the extensive A. C. Saunders site collections held by the Texas Archeological Research Laboratory at The University of Texas at Austin. Lance Trask prepared Figures 1 and 2 for this article. 


\section{References Cited}

Jackson, A. T.

1935 Ash Mound and Midden Heap, A. C. Saunders Farm, Excavated Oct. 1 to Oct. 10, 1935. MS on file, Texas Archeological Research Laboratory, The University of Texas at Austin.

1936 A Perpetual Fire Site. Bulletin of the Texas Archeological and Paleontological Society 8:134-174.

Kassabaum, M. C.

2019 A Method for Conceptualizing and Classifying Feasting: Interpreting Communal Consumption in the Archaeological Record. American Antiquity, https://orcid.org/00000002-8231-4032, pp. 1-22.

Kleinschmidt, U.

1982 Review and Analysis of the A. C. Saunders Site, 41AN19, Anderson County, Texas. Master's thesis, Department of Anthropology, The University of Texas at Austin.

1984 The A. C. Saunders Site Revisited: A Hasinai Fire Temple? Paper presented at the $26^{\text {th }}$ Caddo Conference, Nacogdoches.

Neck, R. W.

1982 Environmental Analysis of Freshwater Mussels from the A. C. Saunders Site, 41AN19. In Review and Analysis of the A. C. Saunders Site, 41AN19, Anderson County, Texas, by U. Kleinschmidt, pp. 253-264. Master's thesis, Department of Anthropology, The University of Texas at Austin.

Perttula, T. K.

1992 “The Caddo Nation”: Archaeological \& Ethnohistoric Perspectives. University of Texas Press, Austin.

2020 The Ancestral Caddo Ceramic Vessel Sherd and Ceramic Pipe Sherd Assemblage from the A. C. Saunders Site (41AN19) in the Upper Neches River Basin, Anderson County, Texas. Caddo Archeology Journal 30:5-60.

Perttula, T. K. and M. Walters

2016 Caddo Archaeology in the Caddo Creek Valley of the Upper Neches River Basin, Anderson and Henderson Counties, Texas. Special Publication No. 43. Friends of Northeast Texas Archaeology, Austin and Pittsburg.

Robinson, D. G., with a contribution by M. B. Shoberg

2020 The 2002 Texas Archeological Society Field School Excavations at the Edd Melton Site (41BL1138), Bell County, Central Texas. Bulletin of the Texas Archeological Society 91:43124.

Wyckoff, D. G. and T. G. Baugh

1980 Early Historic Hasinai Elites: A Model for the Material Culture of Governing Elites. Midcontinental Journal of Archaeology 5:225-283. 